\title{
The Periodic Table of Industries: Detection of Collaboration Opportunities Based on an Imitation of the Mendeleev Periodic Table of Elements
}

\author{
Ibrahim Koura $^{1 *}$, Frederick Benaben ${ }^{1}$, Juanqiong Gou ${ }^{2}$, \\ and Audrey Fertier ${ }^{1}$ \\ ${ }^{1}$ IMT Mines Albi, Allée des sciences, 81000 Albi, France \\ ${ }^{2}$ Beijing Jiaotong University, Haidian District, Beijing 100044 P. R. China \\ Ikoura@mines-albi.fr, Frederick.Benaben@mines-albi.fr, jqgou@bjtu.edu.cn, \\ Audrey.Fertier@mines-albi.fr
}

\begin{abstract}
The concept of collaborative networks has been encountered very often lately as the answer when trying to adapt and improve enterprises in these highly competitive business environments, therefore the urge for constantly addressing this topic. A lot of work-related to collaborative networks has been done so far, from defining network types to leveling partnerships and proposing models for partnership developments. But the lack of tackling a very important obstacle, which is the difficulty of detecting and anticipating collaboration opportunities between enterprises, inspired this research. In this article, a new theoretical opportunity detection approach is proposed based on enterprise characterization concept, KPI classification as well as collaboration types. This detection approach is a table of industrial classifications that imitates the Mendeleev periodic table from the concept point of view. A fictional example from an industrial context is shown to explain the usage of this approach accompanied by discussion about future work and limitations.

Keywords: Collaborative Networks, Enterprise Characteristics, Opportunity Detection, Network Categorization, KPI Classification.
\end{abstract}

\section{Introduction}

Nowadays, companies face a lot of difficulties to successfully respond to a worldwide market condition that is always competitive. Collaboration between organizations is a promising way to help companies widening their offering capacities and reinforcing their competitiveness [1]. In

\footnotetext{
*Corresponding author

(C) 2020 Ibrahim Koura, Frederick Benaben, Juanqiong Gou, and Audrey Fertier. This is an open access article licensed under the Creative Commons Attribution License (http://creativecommons.org/licenses/by/4.0).
}

Reference: I. Koura, F. Benaben, J. Gou, and A. Fertier, "The Periodic Table of Industries: Detection of Collaboration Opportunities Based on an Imitation of the Mendeleev Periodic Table of Elements," Complex Systems Informatics and Modeling Quarterly, CSIMQ, no. 25, pp. 32-53, 2020. Available: https://doi.org/10.7250/csimq.2020-25.03

Additional information. Author ORCID iD: I. Koura - https://orcid.org/0000-0002-7144-1474, F. Benaben https://orcid.org/0000-0002-1676-6524, J. Gou - https://orcid.org/0000-0003-4445-8462, and A. Fertier - https://orcid.org/00000003-3083-3380. PII S225599222000145X. Received: 6 November 2020. Accepted: 9 December 2020. Available online: 31 December 2020. 
this research, we will make an analogy of the Mendeleev table of elements that will imitate the concept of collaboration between chemical elements and apply this concept to predict and suggest potential collaboration for enterprises.

These days, significant changes are occurring in the economy towards progressively adaptable system associations which are devoted for helping to improve the adaptability, ability to quickly set up and maintain partnerships, as discussed in [2], [3]. Working cooperatively could contribute fundamentally to the accomplishment of the business, conveying various business benefits including cost savings, increased sales, knowledge transfer and access to new markets, increased capacity, and improvements in efficiency and effectiveness as said in [4].

Nonetheless, there might be some limitations to the network. Culture diversity, conflicts in the style of working, or overshadowing could be a negative perspective if not managed accurately. Likewise, the timing could be an issue. Gathering information or checking with other collaborators on each decision can moderate the process. It also can cause things to go quicker to meet the needs of the system. In this manner having harmony between those perspectives is important to have a decent collaboration as presented in [5]. Furthermore, enterprises would want to measure the success of their collaboration and whether this collaboration is worth developing and enhancing or not. Hence, here comes the use of the KPI concept and classifications.

However, the essential questions are how these enterprises could outline, assemble, and build their collaborations and how could they optimize their partnership choices and benefit from each other as much as possible. Thus, the research presented in this article aims to propose a conceptualized model to suggest potential collaborations based on the KPIs of enterprises. This theoretical model is a table of industries that imitates the Mendeleev periodic table for suggesting a potential collaboration between enterprises to help improve their businesses and to benefit from each other as much as possible. The business question behind the concept described above can be as follows:

How can enterprises outline, assemble, and build their collaborations and how can they optimize their partnership choices and benefit from each other as much as possible based on their KPIs needs.

We assume that enterprises are aware of the benefits of collaboration, but they do not know with whom they could collaborate to optimize their benefits. Thus, in this research, we address the formation and emergence of collaboration networks for enterprises based on their KPIs.

Based on this business question, we can conclude 5 main scientific questions that are directly related to this research. The first scientific question is considered to be the root question, and the rest of scientific questions are related to it as shown in Figure 1.

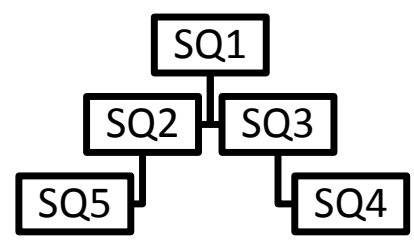

Figure 1. Scientific question structure

SQ1: What are the types of collaborative networks? This question is elevated to classify the resulted proposed potential collaboration network of partners into types that can have different properties. In this question, we try to figure out what are the types of collaborative networks that exist.

SQ2: What are the characteristics of an enterprise profile that are correlated with the Collaboration Network? This question is identified to create a standard enterprise profile with specific characteristics that will help in recognizing the suitable potential partner for each enterprise. 
SQ3: What are the types of collaboration? This question is proposed to identify the various types of collaboration that the organizations can have inside the collaborative network. This question is not similar to SQ1, as here we want to find the type of collaboration between partners within a collaboration network.

SQ4: What are the collaborative need types associated with collaboration? This question raised when we tried to identify the collaborative needs of organizations associated with types of collaboration. A collaborative need is a lack of collaboration; thus any collaboration is an answer to a collaborative need even if it is an unknown or unobvious collaboration, which also indicates that collaborative need types have a direct relation with the collaboration types described in SQ3.

SQ5: What are the KPIs that are related to a collaborative situation? This question is proposed to identify the KPIs that can influence the collaboration decision of an organization. Link between KPIs and the types of collaboration will be proposed and explained in detail in Section 2.

This article will include an explanation for the characterization of an enterprise/organization, the collaboration benefits, the limitations, and the types of collaboration networks. A new hypothesis will be proposed based on a link between an industrial classification criterion and KPI classification which will rank and suggest collaboration possibilities for companies and, at the same time, act as a base for the concept of the periodic table of industries proposed. Section 2 presents the background and related work literature review respectively. Section 3 discusses the approach of this research which is theoretical, and Section 4 presents a fictional example that explains and illustrates the approach. Section 5 concludes the article and suggests future work that will improve this approach.

\section{Background and Related Work}

The authors made requests on Web of Science and Google scholar using the following search string ((KPI OR "performance indicators" OR "performance indicator") AND (((partnership* OR collaboration) AND (opportunity OR opportunities OR detection)) OR (collaboration AND network*) OR ("collaborative network" OR "collaborative networks" OR "enterprise networks" OR “Collaboration situation"))). The results were as shown in Figure 2.

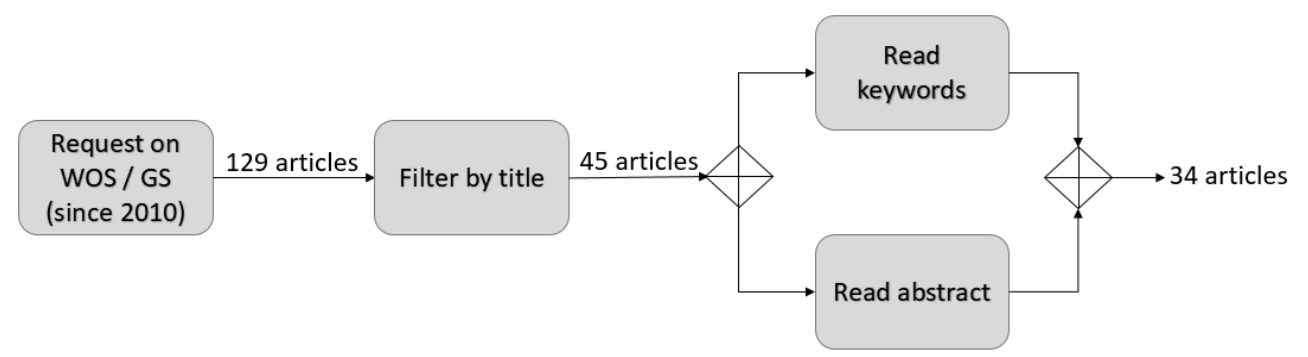

Figure 2. Steps of searching for the current literature review

In this request, the authors were searching for topics that are related to collaboration detection or collaborative situations involving KPI management or KPI classification during the period between 2010 to 2020 . The initial result of the search was 129 articles which were reduced to 34 by title, keywords, and abstract filtering.

The literature review articles were divided into two areas. Areas A and B are the classifications of these articles based on the area of interest regarding the business and scientific questions discussed earlier. Area A represents competitor research work and contribution, and area $\mathrm{B}$ represents inspirational research work and contribution. The competitor research work and contribution discusses the characteristics and types of collaborative networks as well as the creation and maintaining of these networks, mainly answering the business questions. Also, it discusses some previous models that propose partnerships for enterprises and provide a comparison between their objective and the objective of this article. Inspirational research work and contribution mainly 
discusses the scientific questions like performance indicators and their relationship with collaboration networks. It also inspired the idea of this research to use the impact of KPIs on the collaboration networks to propose the best partnerships for enterprises.

Table 1 presents all 34 articles selected. The reference, idea, and the purpose of each article are shown along with the area of interest.

Table 1. Literature review articles and their area of interest

\begin{tabular}{|c|c|c|}
\hline Ref. & Idea/Method & $\begin{array}{l}\text { Area of } \\
\text { interest }\end{array}$ \\
\hline [1] & $\begin{array}{l}\text { This paper discusses the cooperation between collective and individual capabilities, } \\
\text { competencies and value transactions in collaborative environments. }\end{array}$ & A \\
\hline [2] & $\begin{array}{l}\text { This paper presents the integration between graph theory and scientific disciplines. This } \\
\text { integration enables modeling complex, non-tangible factors and dynamics trade-offs between } \\
\text { individual and common objectives, issuing in the building and management of Virtual } \\
\text { Organizations. }\end{array}$ & A \\
\hline [3] & $\begin{array}{l}\text { The purpose of this paper is to survey the potential contributions concerning the assessment of } \\
\text { collaborative benefits and performance. The analysis also determines the strengths and } \\
\text { weaknesses of current proposals regarding the establishment of suitable performance indicators } \\
\text { for collaborative business ecosystems. }\end{array}$ & $\mathrm{B}$ \\
\hline [4] & $\begin{array}{l}\text { The purpose of this paper is to discuss a possible perspective on future research in the area of } \\
\text { networked organizations, given its evolution during the past } 10 \text { years. }\end{array}$ & B \\
\hline [5] & This paper addresses a series of issues that companies face when forming a strategic alliance. & $\mathrm{B}$ \\
\hline [6] & $\begin{array}{l}\text { The purpose of this paper is to analyze different methods for synchronizing supply chain and } \\
\text { processes between organizations such as EDI. Also, a cost and benefits framework for this issue } \\
\text { is discussed. }\end{array}$ & A \\
\hline [7] & $\begin{array}{l}\text { An enterprise characterization is proposed which is used in a theoretical approach that also } \\
\text { involves KPI classification and ranking. }\end{array}$ & $\mathrm{B}$ \\
\hline [8] & $\begin{array}{l}\text { The authors introduce the undivided business process demonstrating the approach for } \\
\text { collaborative enterprise modeling, which involves the lean concepts for partner selection. }\end{array}$ & $\mathrm{A}$ \\
\hline [9] & $\begin{array}{l}\text { A simulation model is formed to show organizations how to self-adjust themselves using system } \\
\text { dynamics and agent-based modeling. This happens by improving their profile in response to an } \\
\text { assessment through a chosen set of performance indicators. Also, the natural reaction of } \\
\text { organizations towards improving their performance is modeled. }\end{array}$ & $\mathrm{B}$ \\
\hline [10] & $\begin{array}{l}\text { A set of organizational models, collaborative behavior patterns, and collaboration facilitation } \\
\text { mechanisms are identified and classified based on nature-related disciplines. Also, analysis } \\
\text { results on the potential contribution of such aspects to a more intelligent and } \\
\text { optimized collaborative networks area are presented. }\end{array}$ & A \\
\hline [11] & $\begin{array}{l}\text { In this paper, areas of performance indicators are examined along with collaboration benefits, } \\
\text { value systems, supply chain collaboration, and business network analysis. This paper also } \\
\text { discusses the strengths and weaknesses of proposals regarding the establishment of suitable } \\
\text { performance indicators for collaborative business ecosystems. }\end{array}$ & A \\
\hline [12] & $\begin{array}{l}\text { The purpose of this work is to test and improve an indicator instrument for real-time assessment } \\
\text { of collaborative and dynamic innovation processes. The paper presents an indicator tool resulted } \\
\text { from successful long-term collaborative innovation across organizational and international } \\
\text { borders and releases initial tests to validate five performance indicators for flexible innovation. }\end{array}$ & B \\
\hline [13] & $\begin{array}{l}\text { A decision support system is proposed, consisting of a mathematical model, a system dynamics } \\
\text { method, and a simulation tool, to aid the process of analyzing aligned strategies, among the } \\
\text { enterprises of the collaborative network. }\end{array}$ & B \\
\hline$[14]$ & $\begin{array}{l}\text { This research presents an approach to project business process monitoring and identifies the key } \\
\text { forms of virtual enterprise process evaluation. A framework is presented with special } \\
\text { significance in linking interest groups to the development of their targets, information, and } \\
\text { knowledge sharing. }\end{array}$ & B \\
\hline$[15]$ & $\begin{array}{l}\text { This paper's goal is to investigate factor affecting causal relationship of the supply } \\
\text { chain collaborative model as well as the supply chain performance measurement model for the } \\
\text { Thai frozen shrimp chain. }\end{array}$ & $\mathrm{A}$ \\
\hline$[16]$ & $\begin{array}{l}\text { This paper aims to propose a bibliometric review on collaborative networks (2002-2015) } \\
\text { regarding the domains of innovation and operations management. This paper displays the } \\
\text { origins and evolution of collaborative networks over time by analyzing the references from the }\end{array}$ & $\mathrm{A}$ \\
\hline
\end{tabular}




\begin{tabular}{|c|c|c|}
\hline Ref. & Idea/Method & $\begin{array}{l}\text { Area of } \\
\text { interest }\end{array}$ \\
\hline & most important academic contributions. & \\
\hline [17] & $\begin{array}{l}\text { This paper focuses on the study of the evolution of the agents of a collaborative business } \\
\text { ecosystem. This study depends on the performance indicators to assess their performance and } \\
\text { considering their class of responsiveness. }\end{array}$ & $\mathrm{A}$ \\
\hline [18] & $\begin{array}{l}\text { A system is proposed to support the process of collaboratively selecting the strategies in } \\
\text { enterprise networks to achieve higher alignment levels selection of strategies. The proposed } \\
\text { system considers the impacts that each strategy, formulated in each enterprise, has on the } \\
\text { performance of the objectives defined by each network partner. }\end{array}$ & $\mathrm{B}$ \\
\hline [19] & $\begin{array}{lllll}\text { This paper proposes a set of performance indicators to measure } & \text { some } & \text { of } \\
\text { the collaboration benefits. The presented results are based on simulation models. } & & \\
\end{array}$ & $\mathrm{A}$ \\
\hline [20] & $\begin{array}{l}\text { This paper proposes a simulation model to support enterprises in the decision making on } \\
\text { which proactive strategies trigger to be aligned from a collaborative perspective. }\end{array}$ & B \\
\hline [21] & $\begin{array}{l}\text { This paper presents the application of a methodology that allows the generation of business } \\
\text { scenarios based on the performance of the collaboration network. It also defines the KPIs as } \\
\text { well as designing a business scenario based on the timely evolution that the collaboration } \\
\text { network should have according to its business models and operations results achieved. }\end{array}$ & $\mathrm{B}$ \\
\hline [22] & $\begin{array}{l}\text { This paper presents the literature review of collaborative networks, business ecosystems, } \\
\text { enterprise performance indicators, business networks analysis, and supply chains. }\end{array}$ & $\mathrm{A}$ \\
\hline [23] & $\begin{array}{l}\text { This paper aims to present an approach based on the Analytic Network Process to } \\
\text { manage collaborative relationships under an integrated approach by considering factors that } \\
\text { influence collaboration and the inter-enterprise performance elements. }\end{array}$ & $\mathrm{B}$ \\
\hline [24] & $\begin{array}{l}\text { The purpose of this paper is to present a literature review of factors } \\
\text { affecting collaborative relationships to perform a comparative study of the works for } \\
\text { identifying strengths and gaps for future research. }\end{array}$ & $\mathrm{B}$ \\
\hline [25] & $\begin{array}{l}\text { This paper proposes an approach that leads to the exploration of the performance prediction } \\
\text { paradigm. Also, it develops tools to estimate and evaluate the performance and the degree of } \\
\text { alignment by creating instances of future performance in collaborative networks. }\end{array}$ & $\mathrm{B}$ \\
\hline [26] & $\begin{array}{l}\text { This paper describes the concepts of collaboration, background concepts of virtual } \\
\text { enterprises, and requirements of collaboration. }\end{array}$ & $\mathrm{A}$ \\
\hline [27] & $\begin{array}{l}\text { This article discusses the main characteristics on which the Virtual enterprise structure } \\
\text { depends, in alignment with environmental constraints, production process, and strategic } \\
\text { objectives. }\end{array}$ & $\mathrm{A}$ \\
\hline [28] & $\begin{array}{l}\text { This paper proposes a decision model from a micro viewpoint. This model can be used to } \\
\text { specify its current partnership strategy and determine its future partnership strategy with } \\
\text { another company. }\end{array}$ & $\mathrm{B}$ \\
\hline [29] & $\begin{array}{l}\text { This article discusses the concept of collaborations through an examination of different levels } \\
\text { of trust and complexity. }\end{array}$ & $\mathrm{B}$ \\
\hline [30] & $\begin{array}{l}\text { This paper focuses on extracting essential forms of firm capabilities in the context of } \\
\text { decision-aid to support the identification of collaborative networks. }\end{array}$ & $\mathrm{A}$ \\
\hline [31] & $\begin{array}{l}\text { This book discusses the opportunities for collaboration and the effects and benefits of } \\
\text { collaborative working practices and their impact on supply chain performance. }\end{array}$ & A \\
\hline [32] & $\begin{array}{l}\text { This paper discusses the analytical modeling on the relationship between supply chain } \\
\text { collaboration and performance improvement. It also offers industry-based empirical results } \\
\text { on consolidated practical and theoretical insights. }\end{array}$ & $\mathrm{B}$ \\
\hline [33] & $\begin{array}{l}\text { In this paper dimensions of KPIs are presented that are helpful for collaborative networks as } \\
\text { well as individual enterprise measurements. }\end{array}$ & A \\
\hline [34] & $\begin{array}{l}\text { This paper aims to understand the impact of collaborations on firm innovation performance. } \\
\text { A use case from Turkey is also presented. }\end{array}$ & A \\
\hline
\end{tabular}

All articles that are classified in Area A (inspirational research work) discuss the concepts of collaborative networks that are related to the business question. These articles will be used in the further subsections for discussing in more detail the types and levels of collaborative networks, benefits and limitations of collaborative networks, and network topologies.

The articles that are classified in Area B (competitor research work) discuss the scientific questions stated earlier, like the relation between performance indicators in collaborative networks, and how can they influence the strategy of forming partnerships. During the study of the literature, we came across some previous work done that suggested models to detect potential 
collaboration partners (e.g, UNICOMP in [30]) and also concepts that enhance the partner selection process (e.g., [8]). However, we did not come across any model that used the KPIs of an enterprise to suggest potential collaboration partners.

In the coming subsections, the competitor research work and contribution articles are discussed to study the previous work done that has a relation with the concept of this article.

\subsection{Collaboration Network Types}

First of all, we need to know what a collaborative network is. A Collaborative Network $(\mathrm{CN})$ is frequently introduced as a network consisting of a variety of elements (e.g., organizations and individuals) that are largely autonomous, geographically distributed, and heterogeneous as far as their working condition, culture, business capital, and goals. These elements can collaborate to better achieve common or compatible goals, and whose interactions are supported by computer networks as stated in [35], [36].

They will often collaborate on commercial ventures such as the development of new products, penetration of new markets and improvement of existing processes, buying and selling finished or non-finished goods, and so on. These networks vary in types and the benefits they serve to the members, which also present some limitations to the process of collaboration.

Depending on the collaboration objective of each industry, there are different types of networks that can be formed to suit different types of benefits. Business networks may offer the members access to resources that would be difficult for a single business. Individual businesses can confront various constraints when attempting to contend in worldwide markets, this may incorporate scale and ability. The result of collaboration for this approach can be of any type of these networks. There are diverse examples of network types that can be an output of a collaboration process, the four most famous examples are shown below [4], [26], [27], [36].

- Extended Enterprise (EE) - an association that is dominant in an industry and broadens its limits to all or a portion of its suppliers.

- Virtual Enterprise (VE) - a temporary partnership of industries that collaborate to share abilities to react to business openings. An extended enterprise is a case of a VE.

- Virtual Organization (VO) - like a VE, a set of autonomous associations that share resources and skills to achieve a goal, but still is not constrained to a partnership revenue driven venture. A VE is a specific instance of VO.

- VO Breeding Environment (VBE) - a group of organizations and their related supporting parties that have both the potential and the will to collaborate. A subset of these associations can be chosen and subsequently forming a VE or VO.

\subsection{Collaborative Network Benefits}

The mutual benefits that are achieved by collaboration are categorized below as stated in [3] and [6].

- Financial benefits - the financial benefits of being part of a network can include an increase in domestic or export sales, submitting a joint tender to win larger contracts, or a reduction in costs by sharing resources.

- Human capital - the staff benefits can include developing employee's skills and abilities, safeguarding jobs, increasing employment, and encouraging staff motivation.

- Physical capital - the benefits of being part of a collaboration network can have an impact on the physical capital of the business by supporting the sharing of facilities, raw materials, and equipment.

- Intellectual capital - the intellectual capital of an organization can benefit through information-sharing, assurance in collaborative research and development, and design 
activities. They may account for other company's complementary strengths, capabilities, and share best practices.

- Develop new processes - joining a collaborative network can support a business in developing new or innovative products, processes, or services. It may help in increasing company knowledge of a marketplace to help identify potential new customers and allow them to compete more effectively.

- Sustainability - joining a network could help develop the concept of sustainability of a system. For instance, to increase the number of green enterprises.

These benefits inspire the types of expected KPI benefits for enterprises when taking part in collaboration as will be explained in detail in Section 3.

\subsection{Collaborative Network Limitations}

However, there are some limitations and risks to network collaboration as stated in [5] and [37].

- Conflicts in working styles - This can be a major problem when different organizations collaborate on a project. There may be a conflict in the style of working within the network. This can end up holding up progress on accomplishing the job at hand, while organizations disagree and cause conflicts in different ways they approach the work. This can be very real when we have a collaborative group; we may sometimes end up with too many enterprises trying to lead the network. This will result in not enough members that are willing to do what it takes to get the job done.

- Cultural diversity - It could be seen as a positive aspect if we tried to benefit from this diversity by putting all the experiences of the parties on the table, but at the same time, it could be a negative one if not approached correctly like trying to force one way of working style over the rest of the parties in a network.

- Personality overshadowing - Another conflict could occur when the stronger enterprise is so influential than other parties in the network that its representatives manage to take over the discussion and force their ideas as the result. Also, it can be difficult for enterprises to be comfortable in a situation where they feel that their ideas are shared within a network.

- Timing - Collaborations can mean that a campaign moves more slowly because of the need to gather information, make agreements, or check with the other players regarding every decision. On the contrary, collaboration may force us to have to do things faster or earlier than expected because of the expectations of the network which forces us to do so. That is why there should be a good understanding of the levels of self-sufficiency of companies. Working in a group can also mean that sometimes people may not be as efficient in timekeeping as they could be if working autonomously. Organization and timekeeping are very important in tasks with a deadline; if people do not pull their weight in tasks they may fall behind the schedule.

These limitations inspired the analysis of KPI effect for enterprises on the collaboration parties as will be discussed in Section 3.

\subsection{Industrial Classification and Types of Collaboration}

The variety in network types, benefits, and limitation create difficulty for a company to find the suitable collaboration it requires, and the members that it needs to form a network with. As stated in [7], to help enterprises form collaboration, an enterprise profile should be defined first. There are many characteristics that can distinguish and define an enterprise.

The characteristics of the profile as seen in [7] are performance, size, industrial type, type of benefit desired, and collaboration capability. Some of these characteristics can be measured numerically such as performance, size, and the industrial type; and some cannot - such as the type of benefit desired and collaboration capability. 
While many different characteristics can be used to define an enterprise profile, here we will be using the five characteristics mentioned in [7]. This profile will be used in identifying the potential collaboration partner/s in a network. Any subsets of the five characteristics forming the profile could be a significant way to characterize organizations. In this research, we will only consider one specific characteristic which is the type of industry (NACE code). Because the industrial type is related to the business of an enterprise, this characteristic is incredibly significant to collaboration properties. The information about the other characteristics is not easily available due to different obstacles like legal issues. We know that considering only the type of industry is not perfectly accurate for creating a model to propose potential partners. However, we see the proposed model as a usable start to a more complex and inclusive work (that can consider more characteristics for creating a model).

This NACE code classifies all industry types into 4 levels: sections, divisions, groups, and establishing classes. The criteria for grouping in such divisions, groups, and classes are discussed in the official European commission document [38]. Considering the classification criteria of groups, a hypothesis was proposed as follows.

"If the type of business of any enterprise can be identified as one or more industrial classes from the NACE code, a potential collaboration link can be suggested within the same group of this class"

That was claimed because two organizations that exist in the same group can naturally be considered as a potential collaboration partners because they can share the same type of suppliers or both can answer to a market need for a certain project. Also, if they are both competitors, they can have a better opportunity to work together as they share the same production process for instance to produce a new product for the market or agree on a specific selling strategy to better serve both of them. There could be several different collaboration network types, but if we take virtual enterprise (VE) as an example, we can consider the collaborations that would involve similar companies to increase their workforce. So, we will consider that enterprises in the same division are good candidates for collaboration.

Based on partnership types in [7], [28], [29], the list of exchange types is proposed. These types of collaboration between partners can be described as follows:

(1) Owner-Renter, (2) Informer/Advisor-Recipient, (3) Supplier-Integrator, (4) VendorCustomer, (5) Endorsee-Endorser, (6) Provider-Receiver, (7) Co-owners, (8) Co-informers, (9) Co-suppliers, (10) Co-vendors, (11) Co-endorsers, and (12) Co-providers.

This relationship along with KPI classification will be used in Section 3 as part of the approach to suggest potential collaboration for enterprises.

\section{Proposed Approach}

According to the Oxford dictionary, a need is something required because it is important rather than just desirable. The same definition is mentioned in Merriam-Webster as it specifies that a need is a lack of something. However, from business point of view, a need is a motivating force that compels action for its satisfaction as mentioned in [39]. From the previous three definitions of a need, we can extract that there is a relation between a subject that lacks something, and an action that must be done to fulfill a need. This relation can be presented as seen in Figure 3.

In Figure 3, there are four sections: Subject, Need, Something, and Action. Each section has a relationship with all other sections in the context of the need definition. A subject has a need because it lacks something. A subject performs an action which in return satisfies a need.

As stated in the introduction, due to market competitiveness, nowadays, one of the most common business needs for enterprises is pursuing a collaborative relationship to develop and improve their businesses. Therefore, putting in mind the definition of need and its relations in Figure 3, we can extract the term "need" and define it from a collaborative point of view. This can be considered as collaborative demand and is defined as follows: 

organization lacks. This indicates that need types have a direct relation with the collaboration types (described in Table 2).

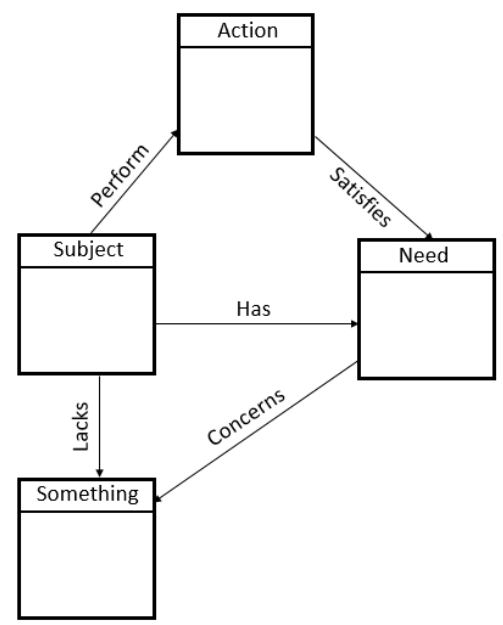

Figure 3. Definition of need

It is necessary to say that to answer any business demand, it is not mandatory to have a collaboration action. Collaboration is one of the actions that can satisfy this demand, and that is what we are focusing on in this research. We can present the demand for collaboration in the context of the need definition as in Figure 4.

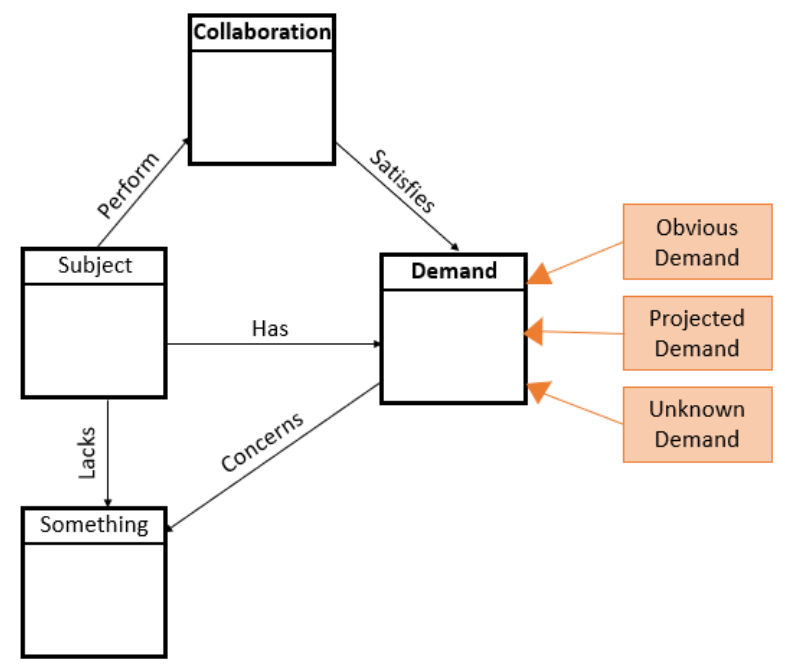

Figure 4. Need for collaboration

As seen in Figure 4, collaboration is seen as the action to satisfy a certain demand for a company. In this research, we propose three types of collaborative demands: Obvious demand, Projected demand, and Unknown demand.

- The Obvious demand is a business demand required by an organization to fulfill its current business activity.

- The Projected demand is a business demand required by an organization to fulfill its current and predictable business activities based on the projected market trend.

- The Unknown demand is a business demand required by an organization to fulfill a new unknown business activity that uses a new business process to introduce a brand-new invention to the market.

We suggest three types of actions that can be defined for such demands as shown in Figure 5. 


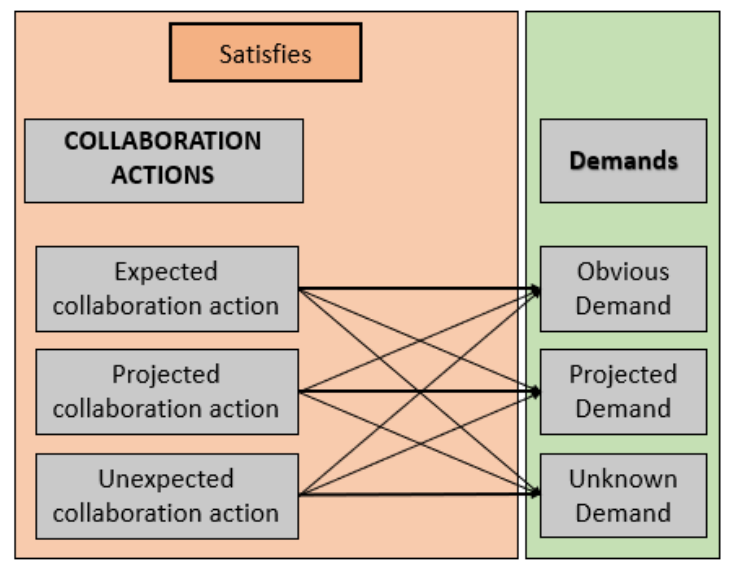

Figure 5. Actions and needs relation

As seen in Figure 5, there are three types of actions connected to all three types of demands. Any type of action can answer to any type of demand. However, we want to specify that for the expected action, it is more likely to answer to an obvious, while it also can answer to any other demand. Likewise, for the emerging action, it is more likely to answer to a projected demand while at the same time it also can answer to any other demand. Finally, the unexpected action is more likely to answer to an unknown demand while it can also answer to any other demand. This will be explained in detail below.

Regarding the assumption of considering collaboration as an answer to business demand, we have defined the three collaboration actions as following. The first type of collaboration action is called the expected action. This type of action satisfies an obvious demand related to the current activity of the company. An example of this action can be a restaurant that buys its raw materials like meat and fruits from its suppliers.

The second type of collaboration action is an emerging action. In this type, an organization wants to follow the trend of the market and probably add some activities or introduce new business processes to their business core, but still be encapsulated in the market trend. An example of that would be a restaurant having collaboration with a transportation company to deliver products to its customers.

And the third type of collaboration action is an unexpected action. This type of action deals with having collaborations that can invent new products or introduce new technology to the market outside the market trend perspective. An example of this type of action is a restaurant having a collaboration to produce intermediary products for cars: Recently Ford has developed a collaboration with McDonald's to produce headlights from coffee waste [40]. From MacDonald's point of view, this can be an example of the unexpected collaboration action because this activity is outside the market trend perspective. However, from Ford's point of view, this can be an example of the emerging action because the same product (headlights) is produced but with a new business process introduced.

In Figure 6, the three collaboration actions are shown concerning the time and market trend perspective. The expected action (black circle) regarding time and market trend tends to be stable, as the expected collaborations are entirely from the current business activity of the enterprise. For this type of collaboration action, the enterprise is stable in the current market trend trajectory. It creates a relationship that is needed to perform the current activity of the enterprise. The simplest example of an expected collaboration action is buying raw materials. 

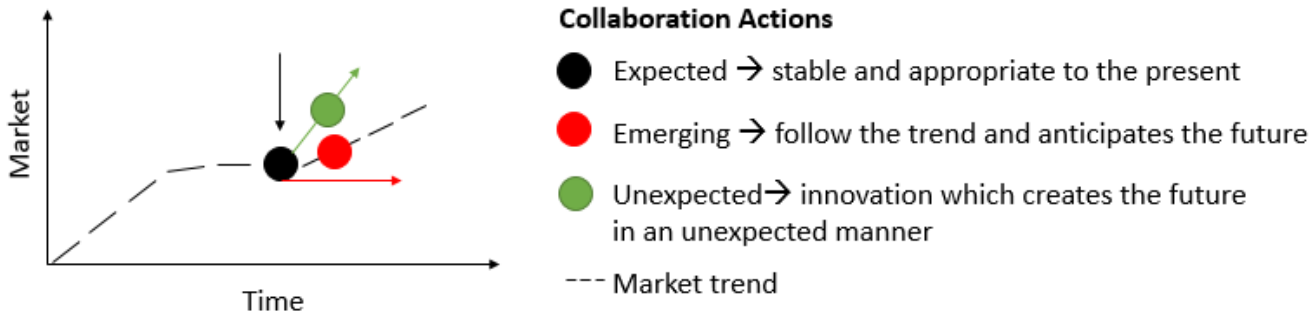

Figure 6. Collaborative action types regarding time

However, the emerging action (red circle) tends to change and adjust the business activity of the enterprise to follow the general evolution of the market trend. In this case, the enterprise is sticking to the market trend trajectory as it is seen in the future and also adjusts to the future needs of the market and gets ready to answer them.

Finally, the unexpected action (green circle) tends to define a new market trend as it creates new business processes and introduces new business activities to the enterprise. In this case, the expected and the emerging trajectories are not followed, however, a new market trend trajectory is defined from scratch. An example of this action could be the invention of the iPhone. To invent this new product, a new collaboration was formed based on an innovation demand. When everyone was expecting the mobile phone design to be smaller, Apple defined a new product which tended to oppose the market trend at this time. The new phones created by apple were bigger in size with a touch screen property as well as integrating a previous device (iPod) and adding an internet browsing tool to the new iPhones.

In the approach of this research, we used the KPI dimensions mentioned in [7] to infer the potential opportunity of collaboration between enterprises. As a first step in creating the periodic table of industries, a general matrix of industrial types was built that shows the type of collaboration between sections (of the NACE code) as in Table 2. This table consists of sections of columns and rows. The industries that are in the columns are considered to be the source to the industries in the rows which will be referred to as beneficiaries. To elaborate more, section A (first row) is going to collaborate with all the sections in the columns (from A to U) along with specifying (within the cell) the type of this collaboration with each of the sections.

Table 2. The relation between industrial types and exchange types

\begin{tabular}{|l|l|}
\hline Sections & A $\quad \ldots . \quad$ U \\
\hline A & $1 / 2 / 3 / 4 / 5 / 6$ \\
\hline KPI & F/M/K/P/R \\
\hline$\cdot$ & \\
. & \\
\hline U & \\
\hline KPI & \\
\hline
\end{tabular}

\begin{tabular}{|l|c|c|}
\hline Divisions & $01 \quad \ldots$. & 99 \\
\hline $\mathbf{0 1}$ & $1 / 2 / 3 / 4 / 5 / 6$ \\
\hline KPI & F/M/K/P/R \\
\hline$\cdot$ & \\
. & \\
\hline $\mathbf{9 9}$ & \\
\hline KPI & \\
\hline
\end{tabular}

Where 1: Resource, 2: Information, 3: Intermediate Product, 4: Final Product, 5: Endorsee/Endorser, 6: Service

The next step of creating the periodic table of industries is to break down the columns and rows into divisions instead of sections. The advantage of this is analyzing the type of industry in a more detailed way which helps in distinguishing between different types of businesses within one section. We also introduced what kind of KPIs would be affected positively or negatively by such types of collaboration.

In Figure 7, an example of some divisions is shown as rows and columns as well as the collaboration types between divisions with the KPI effects on the collaboration types. We will consider $\mathrm{F}$ to be Financial, $\mathrm{K}$ to be knowledge, $\mathrm{R}$ to be resources, $\mathrm{M}$ to be market, and $\mathrm{P}$ to be 
product KPIs as mentioned in [7]. That means that a relationship between a company of division 01 and another company of division 99 can be of a type of collaboration 1/2/3/4/5/6. The KPI row shows which KPIs are impacted by such relation. Figure 7 details that.

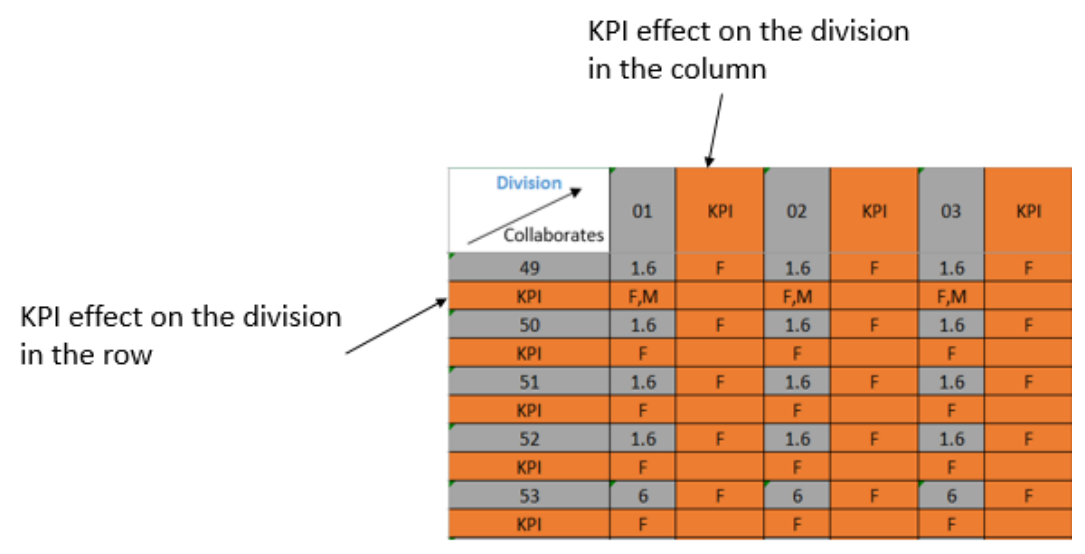

Figure 7. Example of the general matrix of industries

Figure 7 shows a $10 \times 6$ division matrix that is a simple part from the general matrix of industries which is $198 \times 198$ that consists of all divisions in the NACE code, represented horizontally and vertically. The divisions in the columns act as sources to the beneficiaries (divisions in the row). That is why there are KPI lines shown for each row and column from its perspective, respectively. If we take, for instance, the first row, division 49 can collaborate with divisions 01, 02 and 03 with type 1 or 6. This will affect division 49's Financial and Market KPIs. However, this collaboration, from divisions 01, 02 and 03 perspectives, will affect their Financial KPIs only. This general matrix database is built based on real existing collaboration examples along with their collaboration types and their KPI effects. For each cell, the internet was searched to find at least one real existing partnership. Based on the details of this partnership stated on the web, we deduced the type of collaboration. For each type of collaboration deduced, we stated what kind of KPI dimension would be affected due to such collaboration type.

As we know, the NACE code consists of 99 divisions, so this database is $99 \times 99$ matrix which makes it hard to build it manually. Only 8 divisions in the rows and five in the columns are completely defined along with their KPI effect and the rest is not defined due to the complexity of filling each cell. Filling the whole matrix by building a program that searches the internet looking for real examples of collaborations for each division is considered to be a future work. So, if, for instance, the collaboration between division 05 (mining of coal and lignite) and division 13 (manufacturing of textiles) is missing in the matrix. The web will be searched for any existing example of two companies that have a collaboration of any type (between these two division types) and the matrix will be filled along with the KPIs effected from such collaboration.

Thus, came the second idea of creating a periodic table of industrial types that can suggest potential collaboration between enterprises. This table will have sections and divisions as columns and type of collaboration as rows. Each cell will contain all the divisions that are related to a certain collaboration type for such division. For instance, for section A there are two divisions. Each division will be considered as the head of a column. Both will be intersected by 5 collaboration types (rows) as seen in Table 3.

So, let us assume that the original database matrix is full. According to the number of divisions related to another section, both divisions will be moved to be beside each other. We will be using all the information of the original database matrix and present it in another visual way that can be used as an industrial periodic table for suggesting potential collaboration partners based on industrial types (Divisions) and collaboration types. 
Table 3. Example for static periodic table

\begin{tabular}{|c|c|c|c|c|}
\hline & \multicolumn{2}{|c|}{ SECTION A } & SECTION B & SECTION F \\
\cline { 2 - 5 } & Division 01 & Division 02 & $\begin{array}{c}\text { Division } \\
05 \ldots 09\end{array}$ & Division 41 \\
\hline $\begin{array}{c}\text { Collaboration } \\
\text { type 1 }\end{array}$ & $01,49,50,51,52,77$ & $02,05,08$ & & $49,51,52,77$ \\
\hline $\begin{array}{c}\text { Collaboration } \\
\text { type 3 }\end{array}$ & 01 & - & & 01 \\
\hline $\begin{array}{c}\text { Collaboration } \\
\text { type 4 }\end{array}$ & $20,28,46,47$ & 62,64 & & $21,28,45,46,47$ \\
\hline $\begin{array}{c}\text { Collaboration } \\
\text { type 5 }\end{array}$ & 01 & 46 & & - \\
\hline $\begin{array}{c}\text { Collaboration } \\
\text { type 6 }\end{array}$ & $\begin{array}{c}01,49,50,51,52,35,36,43, \\
53,64,65,66,69,70,72,73,75\end{array}$ & $19,20,22,53$ & & $31,32,33,49,50,51,52$, \\
\hline
\end{tabular}

To make this visual representation more like the periodic table of elements, we can show the periodic table of industrial types as depicted in Figure 8.

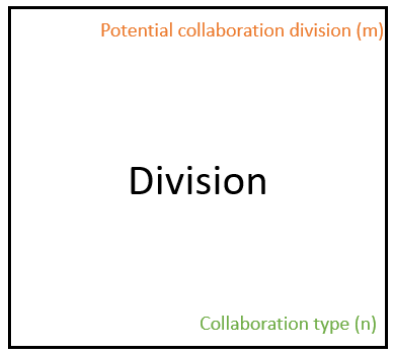

Figure 8. Single industrial type

As seen in Figure 8, the division will be represented in the middle of the square, and the potential collaboration division will be shown on the top right corner of the square, and the type of this collaboration will be shown in the bottom right corner of the square.

So, if we take the previous concept of representing the industrial types, we can represent division 01 that has collaboration with division 36 of type 4 as Figure 9 shows.

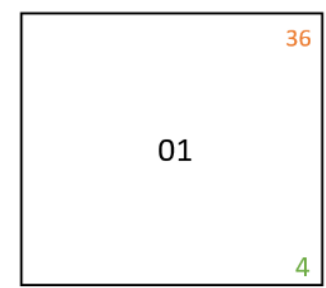

Figure 9. Example of a single industrial type

As seen in Figure 10, this is the representation of the periodic table of industrial types. The columns refer to the division number from the NACE code (D) and the division number increases going right, from 01 to 99 . The rows refer to the potential collaboration division (M) and the type of collaboration $(\mathrm{N})$. Both will vary as we go down the row. The potential collaboration divisions will vary from 01 to 99 . The collaboration type will vary from 1 to 6 . So, as an example, the first column represents division 01. The first cell in the column shows that there is a potential collaboration with division 01 of type 1 . The second cell in the column shows that there is a potential collaboration with division 49 of type 1 and so on. Thus, the potential collaboration division will vary first, then comes the type of collaboration. As seen in Figure 10, the second column starts from division 02 , and the third column starts from division 03 . This 
does not mean that division 01 will not act as a source to division 02 , but this cell will be shown in column 1 as it will be explained further.

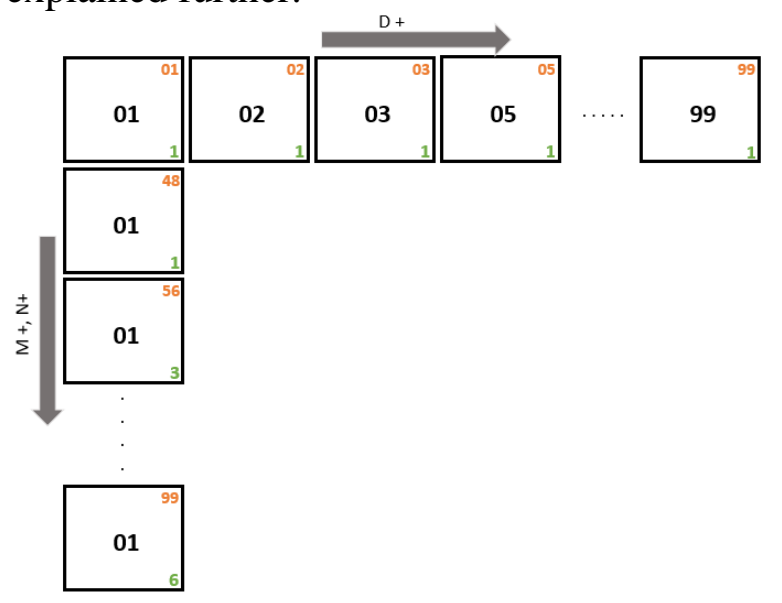

Figure 10. Representation of the periodic table of industries

As said before in the concept of the general matrix, the divisions in the columns will act as sources to the divisions in the rows (beneficiaries). In the periodic table of industrial types we represent this concept by splitting each cell into two sub cells. We will refer to this idea as "zooming in". If we go a further level deep in one of the cells of the periodic table, we will see that the sub cells describe the relations between two divisions and their collaboration types as well as their KPI effect on each relation respectively as shown in Figure 11.

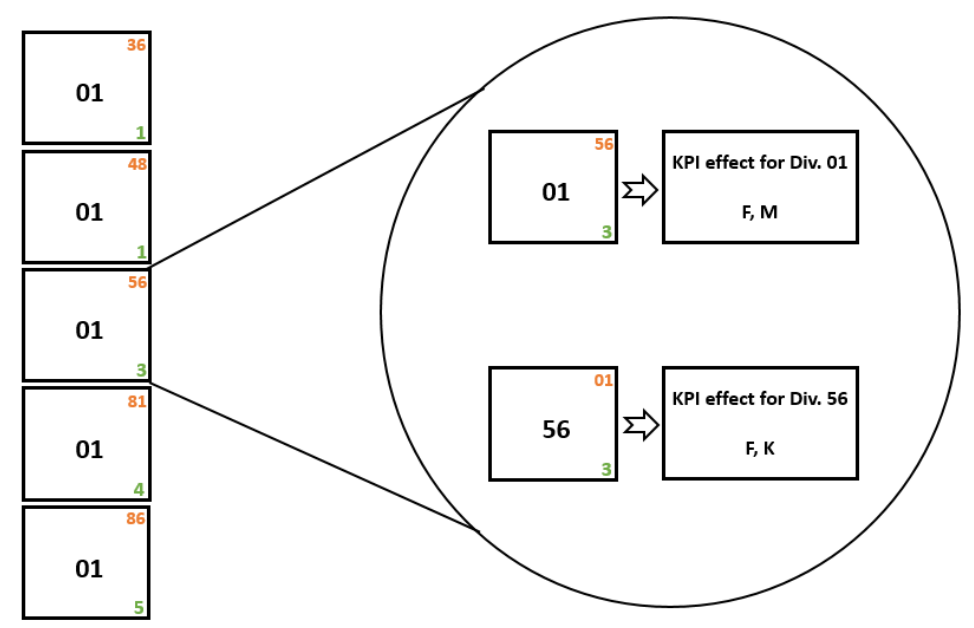

Figure 11. Zooming in level of the industrial periodic table

As seen in Figure 11, the zooming in concept was done on one of the cells that describes that for division 01 there is a potential collaboration with division 56 of collaboration type 3 . The zooming in level allows us to show which division acts as the source and which division acts as the beneficiary. The first sub-cell shows that division 01 is the source to division 56 of collaboration type 3 and this relation will affect the Financial (F) and Market (M) KPIs. The second sub cell shows that division 56 is the source to division 01 of collaboration type 3 and this relation will affect the Financial $(\mathrm{F})$ and Market $(\mathrm{M})$ KPIs also.

For any potential opportunity, there are KPIs that are affected by the collaboration type as mentioned before. Tables 4 and 5 define the relations between the KPIs and the collaboration types. They show how the enterprise KPIs are affected when having a particular collaboration with other parties. The letters in the tables represent the KPIs and the "+" and "-" represent the effect on the KPIs from a collaboration type, whether the KPIs are affected positively "+" or negatively "-". Both tables discuss the types of collaboration regarding the KPI effect (see 
exchange types in Table 2), but we added two more types which are "Hiring new employees" and "Distributing directly to the customers"; both these types deal directly with individuals and not with companies.

In Table 4, when an enterprise is hiring a new employee: This affects the financial KPI negatively as the employee is going to get a salary $(\mathrm{F}-)$. However, the resources KPI is affected positively because now there is new manpower or machinery to be used. $(\mathrm{R}+)$.

When an enterprise is going to rent a resource or buy a product from another enterprise, it is affecting the financial KPI negatively as it is going to pay for this rent/product $(\mathrm{F}-)$. At the same time, the resource KPIs will be affected positively as the resources increased $(\mathrm{R}+)$.

If an enterprise is going to buy information, the financial KPIs are affected negatively because it is been paid for $\left(\mathrm{F}^{-}\right)$. But the knowledge KPIs are affected positively as the information will be improved $(\mathrm{K}+)$.

Same for buying intermediate products: The financial KPI is affected negatively because of the payment $(\mathrm{F}-)$. But the product KPI is affected positively as new products are being introduced to the company $(\mathrm{P}+)$.

Also, for buying an endorsed product (final product): This will affect the financial KPI negatively because of the payment $\left(\mathrm{F}^{-}\right)$. But the product KPI will be affected positively as new products are being introduced to the company $(\mathrm{P}+)$.

Also, for buying a product from a vendor (final product): This will affect the financial KPI negatively because of the payment $(\mathrm{F}-)$. But the product KPI will be affected positively as new products are being introduced to the company $(\mathrm{P}+)$.

Finally, when having another enterprise to perform a service: This will affect the financial KPI negatively for paying for this service $\left(\mathrm{F}^{-}\right)$. But will affect the knowledge, product, resource, or market KPIs positively depending on the nature of this service $(\mathrm{K}+, \mathrm{P}+, \mathrm{R}+$, and $\mathrm{M}+)$.

Table 4. The relation between KPI effect and exchange types (Input)

\begin{tabular}{|c|c|c|c|c|c|c|}
\hline & $\mathbf{0}$ & $\mathbf{1}$ & $\mathbf{2}$ & $\mathbf{3}$ & $\mathbf{4}$ & $\mathbf{5}$ \\
\cline { 2 - 7 } & Hiring & Resource & Inf & I Product & F Product & Service \\
\cline { 2 - 7 } & $\mathrm{F}-$ & $\mathrm{F}-$ & $\mathrm{F}-$ & $\mathrm{F}-$ & $\mathrm{F}-$ & $\mathrm{F}-$ \\
\hline \multirow{3}{*}{$\begin{array}{c}\text { KPI } \\
\text { affected }\end{array}$} & $\mathrm{R}+$ & $\mathrm{R}+$ & $\mathrm{K}+$ & $\mathrm{P}+$ & \multirow{2}{*}{$\mathrm{P}+$} & $\mathrm{P}+$ \\
\cline { 6 - 7 } & & & & & & $\mathrm{K}+$ \\
\hline
\end{tabular}

Where Inf: Information; I Product: Intermediate Product; F Product: Final Product

The same concept is applied in Table 5. When an enterprise is renting its resource to another company, this affects the financial KPI positively as money is going to be paid to the owner $(\mathrm{F}+)$. However, the resources KPI is affected negatively as there will be less manpower or machinery to be used $(\mathrm{R}-)$.

If an enterprise is going to sell information, then the financial KPI is affected positively because it is been paid for $(\mathrm{F}+)$.

Likewise for selling intermediate products, the financial KPI is affected positively because of the payment $(\mathrm{F}+)$. The market KPI is affected positively due to the increase in sales $(\mathrm{M}+)$.

Also, for selling a product to a customer (final product): This will affect the financial KPI positively because a customer will pay for the product $(\mathrm{F}+)$. Also, market KPI is affected positively due to the increase in sales $(\mathrm{M}+)$.

For selling an endorsed product (final product): This will affect the financial KPI positively because a customer will pay for the product $(\mathrm{F}+)$. Also, market KPI is affected positively due to the increase in sales $(\mathrm{M}+)$. 
When performing a service for another company: This will affect the financial KPI positively because a customer will pay for the service $(\mathrm{F}+)$. Also, market KPI is affected positively due to the improvement in sales $(\mathrm{M}+)$.

Finally, when distributing to customers: This will affect the financial KPI positively because a customer will pay for the service $(\mathrm{F}+)$. Also, market KPI is affected positively due to the increase in sales $(\mathrm{M}+)$.

Table 5. The relation between KPI effect and exchange types (Output)

\begin{tabular}{|c|c|c|c|c|c|c|}
\hline & $\mathbf{1}$ & $\mathbf{2}$ & $\mathbf{3}$ & $\mathbf{4}$ & $\mathbf{5}$ & $\mathbf{6}$ \\
\cline { 2 - 7 } & Resource & Inf & I Product & F Product & Service & Dist. \\
\hline \multirow{2}{*}{$\begin{array}{c}\text { KPI } \\
\text { affected }\end{array}$} & $\mathrm{F}+$ & \multirow{2}{*}{$\mathrm{F}+$} & $\mathrm{F}+$ & $\mathrm{F}+$ & $\mathrm{F}+$ & $\mathrm{F}+$ \\
\cline { 2 - 6 } & $\mathrm{R}-$ & $\mathrm{M}+$ & $\mathrm{M}+$ & $\mathrm{M}+$ & $\mathrm{M}+$ \\
\hline
\end{tabular}

Where Inf: Information; I Product: Intermediate Product; F Product: Final Product

As for the sharing situation between companies, we claim that this situation is the same as in the input table (Table 4). Sharing any type of exchange types will increase this exchange type's KPI. For instance, sharing a resource will increase the resource KPIs for both companies, as well as sharing information will increase the knowledge KPIs for both and so on for the rest of the types. However, if both companies decided to give away or sell any type of exchange type, this will affect their financial KPI positively but the KPI of this exchange type will be affected negatively. For instance, if both companies want to sell the resource that they share, both of them will affect their financial KPI positively as they will gain money and both of them will affect their resource KPI negatively as it will be decreased and so on for the rest of the types.

For every opportunity to be seized there must be certain needs to fulfill and benefits to gain. These needs can be fulfilled by introducing new resources to the company, having a consultancy service, etc., depending on the nature of the industry as well as the opportunity itself. A satisfactory status must be reached based on the predicted benefits and predicted costs of needs. So, to determine and rank potential collaborations, the following 5 steps should be followed.

1. Determine which KPIs the company wants to improve;

2. Determine all divisions and their collaboration types that are affected by the KPIs identified in step 1;

3. Compare the KPI effect of each collaboration type with the desired KPI identified in step 1;

4. Filter out the divisions that are not related to the objective of the desired KPI;

5. Decision-making process.

In step 1, the company will determine which KPI(s) dimension(s) they want to improve. Then in step 2 based on the selected KPI(s), the company will determine all divisions and their corresponding collaboration types that are related to the KPIs selected in step 1. In step 3, the effect on the KPIs of each collaboration type will be compared with the desired KPIs identified in step 1 to determine which collaboration type is more suitable. In step 4, the divisions that are not related to the objective of the desired KPI will be filtered. And, finally, in step 5, a multicriteria decision-making process (dealt with like a black box) is applied to rank and choose the best-suggested collaboration partner based on the KPI(s) desired at the beginning.

\section{Illustrative Example}

An example to illustrate the idea of the five steps and the periodic table of industries is as follows. We will consider company A which is in division 49 in the NACE code (Land transport and transport via pipelines) section $\mathrm{H}$ (Transportation and Storage). Company A wants to improve Market KPI (M). In Figure 12, division 49 which represents company $A$ is in the middle. The left part consists of all possible input collaboration types (from 1 to 6) and their 
corresponding KPI effects described in Table 4. The right part consists of all possible output collaboration types (from 1 to 6 ) and their corresponding KPI effects described in Table 5. The numbers on the arrows represent the collaboration types described in previous section.

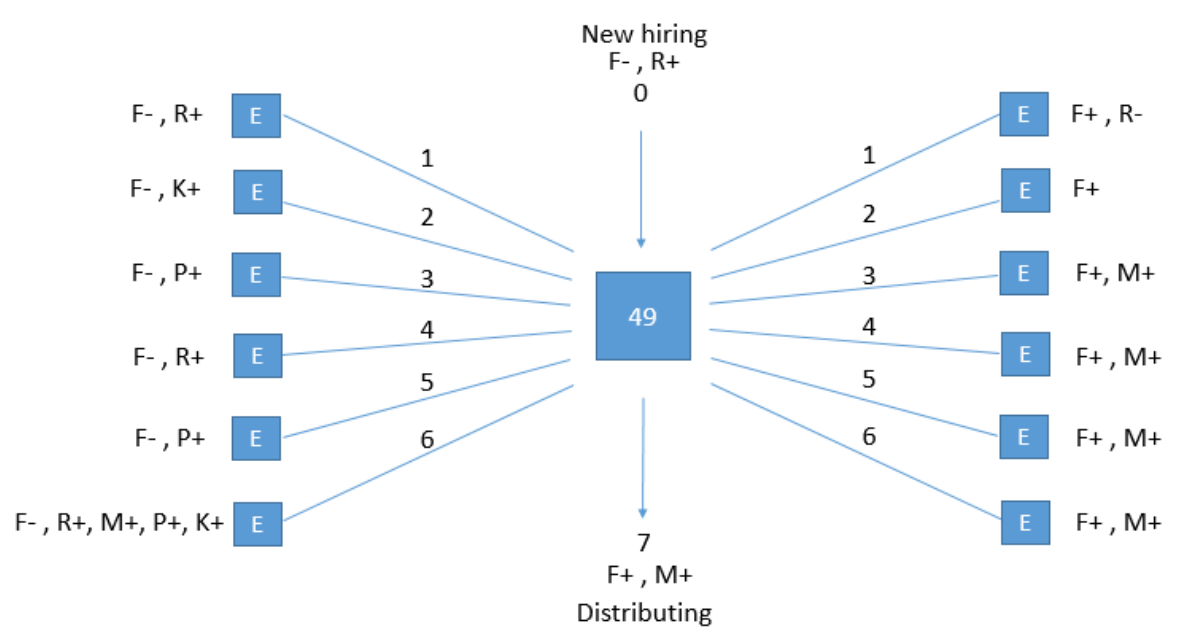

Figure 12. Collaboration type possibilities and their corresponding KPI effect

Company A can have 12 types of collaboration with other enterprises (E), 6 as inputs, and 6 as outputs. The two other collaboration types ( 0 and 7$)$ are for hiring new employees and selling the product directly to customers, which in this case are respectively distributing and delivering to customers. The following explains how the 5 steps, mentioned above for detecting and anticipating collaboration partners would help company A in detecting a suitable collaboration opportunity. Table 6 shows step 1 .

Table 6. Step 1/5 of detecting collaboration partner

\begin{tabular}{|c|c|c|}
\hline Step & Description & Output \\
\hline 1 & $\begin{array}{c}\text { Determine KPIs that want to be } \\
\text { improved }\end{array}$ & $\mathrm{M}$ \\
\hline
\end{tabular}

The next step is to determine from the periodic table of industrial types all divisions and their corresponding collaboration types that are affected by KPI identified in step 1, which is $\mathrm{M}$ (see Table 7)

Table 7. Step $2 / 5$ of detecting collaboration partner

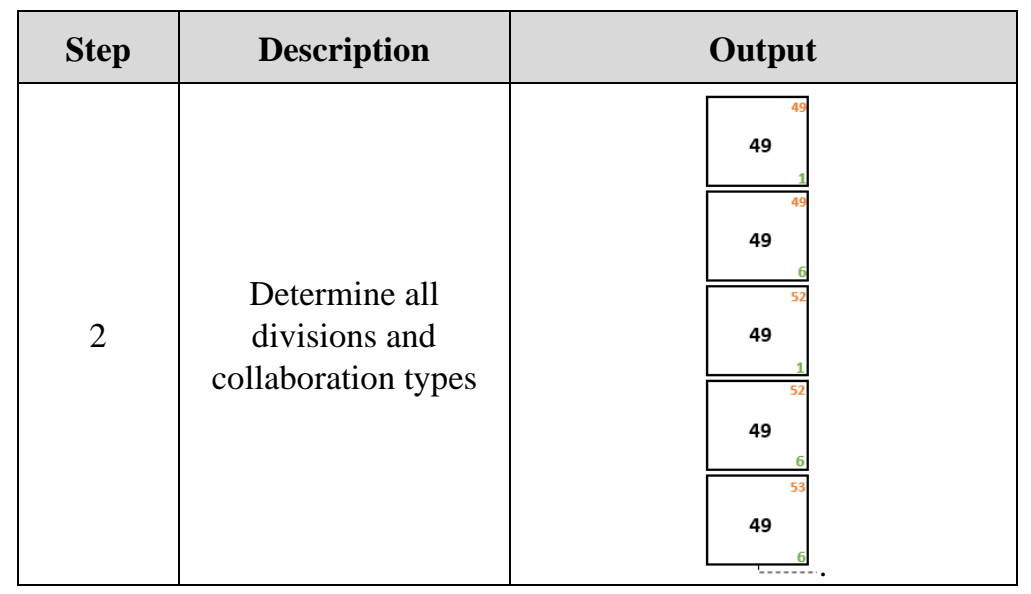


After the zooming in level for each cell, the final divisions and their corresponding collaboration type that are affected by the Market KPI M are shown in Table 8.

Table 8. All divisions that are affected by knowledge KPI

\begin{tabular}{|c|c|c|}
\hline Division & $\begin{array}{c}\text { Potential collaboration } \\
\text { division }\end{array}$ & $\begin{array}{c}\text { Collaboration } \\
\text { type }\end{array}$ \\
\hline 49 & 45 & 4 \\
\hline 49 & 45 & 6 \\
\hline 49 & 49 & 1 \\
\hline 49 & 49 & 6 \\
\hline 49 & 52 & 1 \\
\hline 49 & 52 & 6 \\
\hline 49 & 53 & 6 \\
\hline 49 & 70 & 6 \\
\hline 49 & 73 & 6 \\
\hline
\end{tabular}

The next step is to compare the KPI effect of each collaboration type to the desired KPI identified in step 1 . This is shown in Table 9.

Table 9. Step $3 / 5$ of detecting collaboration partner

\begin{tabular}{|c|c|c|c|c|}
\hline Step & Description & \multicolumn{3}{|c|}{ Output } \\
\hline \multirow{nyyy}{*}{3} & \multirow{2}{*}{$\begin{array}{c}\text { Determine the KPI } \\
\text { effect of each } \\
\text { collaboration type }\end{array}$} & $\begin{array}{c}\text { Collaboration } \\
\text { type }\end{array}$ & Effect on KPI & $\begin{array}{c}\text { The desired } \\
\text { benefit of } \\
\text { KPI }\end{array}$ \\
\cline { 3 - 5 } & $\mathbf{1}$ & $\mathrm{F}-$ & $\mathrm{M}+$ \\
$\mathbf{4}$ & $\mathbf{6}$ & $\mathrm{F}-, \mathrm{R}+$ & \\
\hline
\end{tabular}

The next step is to filter out the unrelated divisions that are not aligned with the objective of the desired KPI. So, from the previous information, we can conclude that only collaboration type 6 is aligned with the desired KPI to improve the Market KPI. This is shown in Table 10.

Table 10. Step $4 / 5$ of detecting collaboration partner

\begin{tabular}{|c|c|c|c|c|}
\hline Step & Description & \multicolumn{3}{|c|}{ Output } \\
\hline \multirow{7}{*}{4} & \multirow{7}{*}{$\begin{array}{l}\text { Filtering out the } \\
\text { unrelated divisions }\end{array}$} & Division & $\begin{array}{c}\text { Potential } \\
\text { collaboration division }\end{array}$ & $\begin{array}{c}\text { Collaboration } \\
\text { type }\end{array}$ \\
\hline & & 49 & 45 & 6 \\
\hline & & 49 & 49 & 6 \\
\hline & & 49 & 52 & 6 \\
\hline & & 49 & 53 & 6 \\
\hline & & 49 & 70 & 6 \\
\hline & & 49 & 73 & 6 \\
\hline
\end{tabular}


The 5th and last step would be using a decision-making process to determine and compare the various options of divisions. The company should calculate the general benefits and compare them to the general cost of the need of applying such collaboration. Accordingly, this will help in choosing, ranking, and defining whether this opportunity is worth taking or not. For this example, we will consider division 70 to be ranked as the first collaboration opportunity as it could improve the desired KPI (M) significantly more than the other potential collaboration divisions (see Figure 13). Division 70 (Activities of head offices, management consultancy activities) includes the provision of advice and assistance to businesses and other organizations on management issues, such as strategic and organizational planning; financial planning and budgeting; marketing objectives and policies; human resource policies, practices, and planning; production scheduling; and control planning. A company in division 70 can provide consultancy services which in this example can be considered as consultation to increase the efficiency of delivery by decreasing the time needed to complete an order or optimizing the route of delivery.

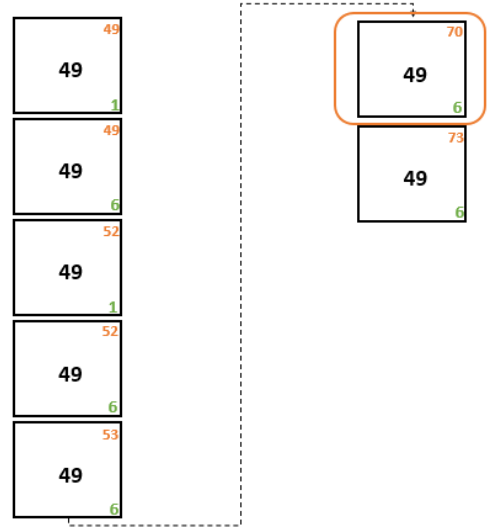

Figure 13. Possible collaboration partners for division 49 as an input to the company

As seen in Figure 13, all collaboration possibilities for division 49 are shown in one column (the dotted line means that the column is completed by the following). The desired collaboration is with division 70, so we can zoom in the cell that has divisions 49 and 70 of collaboration type 6 and two possibilities appear which are the collaboration division 49 to division 70 or division 70 to division 49 (desired) as seen in Figure 14. The cell that represents the collaboration of division 49 and 70 is represented in the column of division 70 and by applying the zooming in level, the sub cell that we are concerned about is the cell where division 70 is the source to division 49.

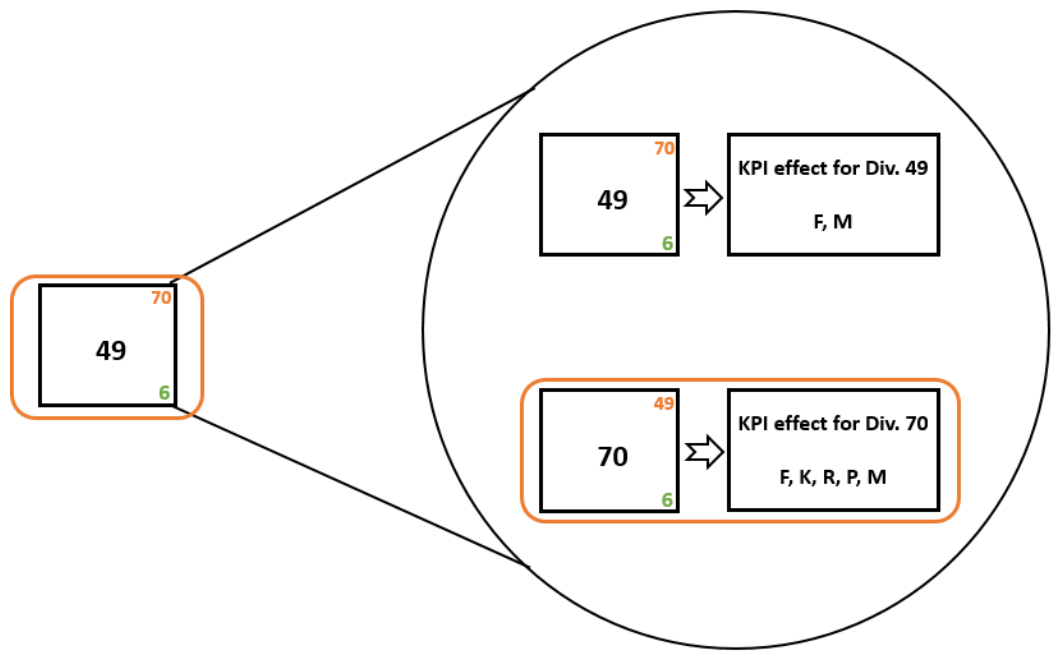

Figure 14. Zoom in level for desired collaboration for division 70 to 49 


\section{Conclusion and Future Work}

This research aims to establish a solution for suggesting a potential collaboration between enterprises to help improve their businesses and to benefit from each other as much as possible. A literature review was presented regarding the business and scientific questions which included network types, benefits, limitations, and performance management. Also, a theoretical approach was proposed that defined six characteristics that would be used as an enterprise profile in a collaborative network. However, only one subset of these characteristics was used which is the type of industry (NACE code) to propose a hypothesis. This potential collaboration can be subjected to several exchange types and links that led to the definition of the 12 collaboration types which were also described. Furthermore, the five KPI dimensions were used to help detect the most suitable partner for collaboration of any type. These dimensions were subjected to a relation with the exchange types between enterprises (resources, information, intermediate product, final product, and service) to define a five-step method that suggests the potential collaboration partner. Finally, an example that explains the five steps was presented.

The approach presented in this research is theoretical and if we want to make it more applicable to the real world, we should include more significant factors that were not addressed in this approach, such as more significant enterprise characterization, more complex and welldefined influences on the KPIs of the enterprise; and also validate this approach using real-world data in a more inclusive use case. A modeling tool could be developed where this approach is digitized (e.g., by employing methodologies such as Agile Modeling Method Engineering [41] to produce a modeling prototype that would serve as a ramp for future validation of the proposal not only with real stakeholders but also in terms of internal qualities: completeness, consistency with requirements, logical consistency, etc.)

One more direction of future research is adjusting this model to introduce the second and third types of needs which are emerging and unexpected. Having these two new need types would enrich the model to suggest more suitable potential partners for companies which would help in improving the market vision of these companies by introducing more opportunities and creating new products.

\section{References}

[1] U. S. Bititci, V. Martinez, P. Albores, and J. Parung, "Creating and managing value in collaborative networks," International Journal of Physical Distribution \& Logistics Management, vol. 34, no. 3/4, pp. 251-268, 2004. Available: https://doi.org/10.1108/09600030410533574

[2] A. L. Soares, J. P. Sousa, and F. Barbedo, "Modeling the Structure of Collaborative Networks: Some Contributions," Processes and Foundations for Virtual Organizations, L. M. Camarinha-Matos and H. Afsarmanesh (Eds.), Boston, MA: Springer, pp. 23-30, 2004. Available: https://doi.org/10.1007/978-0-38735704-1_3

[3] L. M. Camarinha-Matos and A. Abreu, "Performance indicators for collaborative networks based on collaboration benefits," Production Planning \& Control, vol. 18, no. 7, pp. 592-609, 2007. Available: https://doi.org/10.1080/09537280701546880

[4] J. Bacquet, P. Fatelnig, J. Villasante, and A. Zwegers, "An outlook of future research needs on networked organizations," Virtual enterprises and collaborative networks, pp. 17-24, 2004. Available: https://doi.org/10.1007/1-4020-8139-1_2

[5] C. Radu, "Need and potential risks of strategic alliances for competing successfully," Economia. Seria Management, vol. 13, no. 1, pp. 165-169, 2010.

[6] T. McLaren, M. Head, and Y. Yuan, "Supply chain collaboration alternatives: understanding the expected costs and benefits," Internet Research, vol. 12, no. 4, pp. 348-364, 2002. Available: https://doi.org/10.1108/10662240210438416

[7] I. Koura, F. Benaben, and J. Gou, "A Theoretical Approach for Detecting and Anticipating Collaboration Opportunities," Advances in Production Management Systems. Towards Smart Production Management Systems, Springer, vol. 567, pp. 531-538, 2019. Available: https://doi.org/10.1007/978-3-030-29996-5_61

[8] E. Shevtshenko, K. Mahmood, and T. Karaulova, "Enhancing the partner selection process in a Sustainable Partner Network," IFAC PAPERSONLINE, vol. 52, no. 13, pp. 2425-2430, 2019. Available: https://doi.org/10.1016/j.ifacol.2019.11.570 
[9] P. Graca, L. M. Camarinha-Matos, and F. Ferrada, "A Model to Assess Collaboration Performance in a Collaborative Business Ecosystem," Technological Innovation for Industry and Service Systems (DoCEIS 2019), vol. 553, pp. 3-13, 2019. Available: https://doi.org/10.1007/978-3-030-17771-3_1

[10] L. M. Camarinha-Matos and H. Afsarmanesh, "Roots of Collaboration: Nature-inspired solutions for Collaborative Networks," IEEE ACCESS, vol. 6, pp. 30829-30843, 2018. Available: https://doi.org/10.1109/ACCESS.2018.2845119

[11] P. Graca and L. M. Camarinha-Matos, "Performance indicators for collaborative business ecosystems Literature review and trends," Technological Forecasting and Social Change, vol. 116, pp. 237-255, 2017. Available: https://doi.org/10.1016/j.techfore.2016.10.012

[12] C. Weber and K. Sailer, " "The Key Is We" - Refining Co-Creation Indicators to Assess Innovation Processes," Proceedings of the 5th International Conference Innovation Management, Entrepreneurship and Sustainability (IMES 2017), pp. 1107-1118, 2017.

[13] B. Andres and R. Poler, "Supporting the Strategies Alignment Process in Collaborative Networks," Technological Innovation for Smart Systems (DoCEIS 2017), vol. 499, pp. 3-19, 2017. Available: https://doi.org/10.1007/978-3-319-56077-9_1

[14] A. Shamsuzzoha, P. Helo, and M. Sandhu, "Virtual enterprise collaborative processes monitoring through a project business approach," International Journal of Computer Integrated Manufacturing, vol. 30, no. 10, pp. 1093-1111, 2017. Available: https://doi.org/10.1080/0951192X.2017.1285427

[15] S. Pungchompoo and Y. Dunyakul, "Effects of Collaborative Factors on Supply Chain Performance Measurement in Thai Frozen Shrimp Supply Chain," 2017 4th International Conference on Industrial Engineering and Applications (ICIEA), pp. 131-135, $2017 . \quad$ Available: https://doi.org/10.1109/IEA.2017.7939193

[16] F. P. Appio, A. Martini, S. Massa, and S. Testa, "Collaborative network of firms: antecedents and state-of-theart properties," International Journal of Production Research, vol. 55, no. 7, pp. 2121-2134, 2017. Available: https://doi.org/10.1080/00207543.2016.1262083

[17] P. Graca and L. M. Camarinha-Matos, "Evolution of a Collaborative Business Ecosystem in Response to Performance Indicators," Collaboration in a Data-Rich World, vol. 506, pp. 629-640, 2017. Available: https://doi.org/10.1007/978-3-319-65151-4_55

[18] B. Andres and R. Poler, "A decision support system for the collaborative selection of strategies in enterprise networks," Decision Support Systems, vol. 91, pp. 113-123, $2016 . \quad$ Available: https://doi.org/10.1016/j.dss.2016.08.005

[19] P. Graca and L. M. Camarinha-Matos, "A Proposal of Performance Indicators for Collaborative Business Ecosystems," Collaboration in a Hyperconnected World, vol. 480, pp. 253-264, 2016. Available: https://doi.org/10.1007/978-3-319-45390-3_22

[20] B. Andres, R. Poler, and R. Sanchis, "Collaborative Strategies Alignment to Enhance the Collaborative Network Agility and Resilience,” Risks and Resilience of Collaborative Networks, vol. 463, pp. 88-99, 2015. Available: https://doi.org/10.1007/978-3-319-24141-8_8

[21] R. Rodriguez-Rodriguez, J.-J. Alfaro-Saiz, and M.-J. Verdecho, “A Performance-Based Scenario Methodology to Assess Collaborative Networks Business Model Dynamicity," Risks and Resilience of Collaborative Networks, vol. 463, pp. 511-517, 2015. Available: https://doi.org/10.1007/978-3-319-24141-8_47

[22] P. Graca and L. M. Camarinha-Matos, "The Need of Performance Indicators for Collaborative Business Ecosystems," Technological Innovation for Cloud-Based Engineering Systems, vol. 450, pp. 22-30, 2015. Available: https://doi.org/10.1007/978-3-319-16766-4_3

[23] M.-J. Verdecho, J.-J. Alfaro-Saiz, R. Rodriguez-Rodriguez, and A. Ortiz-Bas, "A multi-criteria approach for managing inter-enterprise collaborative relationships," Omega-International Journal of Management Science, vol. 40, no. 3, pp. 249-263, 2012. Available: https://doi.org/10.1016/j.omega.2011.07.004

[24] M.-J. Verdecho, J.-J. Alfaro-Saiz, and R. Rodriguez-Rodriguez, "A Review of Factors Influencing Collaborative Relationships," Adaptation and Value Creating Collaborative Networks, vol. 362, pp. 535-542, 2011. Available: https://doi.org/10.1007/978-3-642-23330-2_58

[25] R. da P. Francisco, A. Azevedo, J. Bastos, and A. Almeida, "Using Key Alignment Indicators for Performance Evaluation in Collaborative Networks," Adaptation and Value Creating Collaborative Networks, vol. 362, pp. 159-166, 2011. Available: https://doi.org/10.1007/978-3-642-23330-2_18

[26] L. Camarinha-Matos and H. Afsarmanesh, "The virtual enterpise concept," Working Conference on Virtual Enterprise, pp. 3-14, 1999. Available: https://doi.org/10.1007/978-0-387-35577-1_1

[27] M. T. Martinez, P. Fouletier, K. H. Park, and J. Favrel, "Virtual enterprise - organisation, evolution and control," International Journal of Production Economics, vol. 74, no. 1-3, pp. 225-238, 2001. Available: https://doi.org/10.1016/S0925-5273(01)00129-3 
[28] C.-Y. Huang and Y.-W. Wu, "Decision model for partnership development in virtual enterprises," International Journal of Production Research, vol. 41, no. 9, pp. 1855-1872, 2003. Available: https://doi.org/10.1080/0020754031000087210

[29] H. Sockett, "Levels of partnership,” Metropolitan Universities, vol. 8, no. 4, pp. 75-82, 1998.

[30] K. Hajlaoui, X. Boucher, and O. Boussaid, "UNICOMP: Identification of Enterprise Competencies to Build Collaborative Networks," Collaborative Networks for a Sustainable World. PRO-VE 2010. IFIP Advances in Information and Communication Technology, Springer, vol. 336, pp. 388-395, 2010. Available: https://doi.org/10.1007/978-3-642-15961-9_46

[31] V. Botta-Genoulaz, J.-P. Campagne, D. Llerena, and C. Pellegrin, Supply Chain Performance: Collaboration, Alignment, and Coordination. John Wiley \& Sons, 2013. Available: https://doi.org/10.1002/9781118558065

[32] A. Vereecke and S. Muylle, "Performance improvement through supply chain collaboration in Europe," International Journal of Operations \& Production Management, vol. 26, no. 11, pp. 1176-1198, 2006. Available: https://doi.org/10.1108/01443570610705818

[33] K. Bauer, "Key Performance Indicators: The Multiple Dimensions," DM Review, New York, vol. 14, pp. 62-66, 2004.

[34] [D. Findik and B. Beyhan, "The Impact of External Collaborations on Firm Innovation Performance: Evidence from Turkey," Procedia - Social and Behavioral Sciences, World Conference on Technology, Innovation and Entrepreneurship, vol. 195, pp. 1425-1434, 2015. Available: https://doi.org/10.1016/j.sbspro.2015.06.439

[35] L. M. Camarinha-Matos and H. Afsarmanesh, "The Emerging Discipline of Collaborative Networks," Virtual Enterprises and Collaborative Networks. PRO-VE 2004. IFIP International Federation for Information Processing, Springer, vol. 149, pp. 3-16, 2004. Available: https://doi.org/10.1007/1-4020-8139-1_1

[36] L. M. Camarinha-Matos and H. Afsarmanesh, "Collaborative networks: a new scientific discipline," Journal of Intelligent Manufacturing, vol. 16, pp. 439-452, 2005. Available: https://doi.org/10.1007/s10845-005-1656-3

[37] B. Andres, R. Poler, L. M. Camarinha-Matos, and H. Afsarmanesh, "A Simulation Approach to Assess Partners Selected for a Collaborative Network," International Journal of Simulation Modelling, vol. 16, no. 3, pp. 399-411, 2017. Available: https://doi.org/10.2507/IJSIMM16(3)3.382

[38] Statistical Office of the European Communities, NACE Rev.2: statistical classification of economic activities in the European Community. Luxembourg: Office for Official Publications of the European Communities, 2008 .

[39] Business Dictionary. Available: http://www.businessdictionary.com/definition/need.html. Accessed on August 18, 2020.

[40] Ford is turning McDonald's coffee waste into headlights. Available : https://edition.cnn.com/2019/12/04/business/ford-mcdonalds-coffee-chaff/index.html. Accessed on December 4, 2019.

[41] D. Karagiannis, "Conceptual modelling methods: the AMME engineering approach," Proceedings of IE 2016, LNBIP, Springer vol. 273, pp. 3-19, 2017. Available: https://doi.org/10.1007/978-3-319-73459-0_1 